\title{
Новые технологические подходы к созданию текстур и согласованию термического расширения в дизайне высокоэффективных кремниевых солнечных фотопреобразователей
}

\author{
(C) С.Е. Никитин ${ }^{1}$, А.В. Бобыль ${ }^{1,2}$, Н.Р. Авезова ${ }^{3}$, Е.И. Теруков ${ }^{1}$ \\ ${ }^{1}$ Физико-технический институт им. А.Ф. Иофффе, Российской академии наук, \\ 194021 Санкт-Петербург, Россия \\ ${ }^{2}$ Санкт-Петербургский государственный электротехнический университет „ЛЭТИ“, \\ 197376 Санкт-Петербург, Россия \\ ${ }^{3}$ Физико-технический институт НПО „Физика-Солнце“ Академии наук Республики Узбекистан, \\ 100084 Ташкент, Узбекистан \\ E-mail: nikitin@mail.ioffe.ru
}

(Получена 18 июня 2018 г. Принята к печати 6 июля 2018 г.)

Рассмотрены причины отказов высокоэффективных кремниевых солнечных фотопреобразователей. Около $30 \%$ отказов происходит из-за образования трещин в кремниевых пластинах и электродах. Механические напряжения, приводящие к образованию трещин, связаны с пирамидальной геометрией текстуры и разностью теплового расширения материалов конструкции. Описана новая методика текстурирования кремния, где функцию зародышей текстуры выполняют преципитаты $\mathrm{SiO}_{x}$, что позволяет получать поверхность состоящую из вогнутых сфероидов субмикронных размеров, резко уменьшающую отражение в области длин волн 330-550нм. Предложен способ согласования теплового расширения элементов конструкции фотопреобразователей с использованием согласующих слоев железоникелевых сплавов, что дает существенное уменьшение вероятности отказов по механизму образования трещин в кремниевых пластинах и отслаивания электродов.

DOI: $10.21883 /$ FTP.2018.13.46886.8938

\section{1. Введение}

Солнечные фотоэлектрические преобразователи (ФЭП) на основе гетеропереходов монокристаллического и аморфного кремния $(c-\mathrm{Si}-a-\mathrm{Si}: \mathrm{H})$ являются одними из самых перспективных с точки зрения соотношения коэффициента полезного действия (кпд) и стоимости. Такие ФЭП носят сокращенное англоязычное наименование HIT (Heterojunction with Intrinsic Thin-layer solar cell) $[1,2]$. Теоретическое значение кпд солнечных ФЭП на основе монокристаллического кремния приближается к $30 \%$ [3].

К настоящему времени кпд промышленных НIT фотопреобразователей достигает 26\% [4]. Очевидно, что потолок кпд ФЭП на основе $c$-Si практически достигнут и на первый план выступают такие характеристики, как время безотказной эксплуатации и себестоимость. По прогнозу International Technology Roudmap for Photovoltaic (ITRPV) к 2024 году деградация мощности для этой разновидности солнечных ФЭП за первый год эксплуатации должна быть не более $2 \%$, гарантийный срок на изделие не менее 10 лет, а общий срок эксплуатации должен быть 30 лет. Вес серебра, используемого для создания системы токоведущих электродов в одной ячейке $(156 \times 156 \mathrm{MM})$, предполагается снизить с 100 мг (2016 г.) до 40 мг (2024 г.) [5]. В связи со сказанным особое внимание исследователей должно быть уделено себестоимости солнечных фотопреобразователей и причинам, приводящим к их быстрой деградации и разрушению.

\section{2. Основные виды потерь и дефектов конструкции, приводящие к снижению кпд и отказам промышленных HIT фотопреобразователей}

Среди дефектов, возникающих в процессе изготовления и эксплуатации кремниевых ФЭП, можно выделить две большие группы: 1 - дефекты, приводящие к быстрому отказу фотоэлектрического преобразователя; 2 потери и дефекты, снижающие эффективность ФЭП, но не приводящие к его быстрому разрушению [6]. К первой группе относятся дефекты, связанные с растрескиванием текстурированных кремниевых пластин с толщинами менее 0.2 мм. Доля отраженной световой энергии для гладкой поверхности кремния достигает 45\% в области длин волн видимого света. Все ФЭП имеют на фронтальной поверхности слой прозрачного проводящего оксида (ППО), отделенный тонким слоем полимера от герметизирующей пластины. В качестве ППО используются слои оксидов цинка и индия, легированных алюминием или оловом $\left(\mathrm{ZnO}: \mathrm{Al}, \mathrm{In}_{2} \mathrm{O}_{3}: \mathrm{Sn}\right)$. Слои ППО имеют коэффициент преломления в диапазоне от 2 до 2.2, а коэффициент преломления полимерного слоя равен 1.41. Если свет, отраженный от поверхности кремния, падает на границу ППО - полимер под углами, близкими или большими угла полного внутреннего отражения, то излучение вновь возврашается в кремниевые активные слои ( $p-n$-переходы). Для максимального увеличения такого эффекта необходимо увеличивать диффузное от- 
ражение излучения от поверхности кремния, что и приводит к необходимости создания текстур с размерами шероховатостей, близкими к длинам волн видимого света (380-1000 нм). Рассеивающие свойства таких текстур должны максимально приближаться к ламбертовской рассеивающей поверхности. Такая поверхность имеет одинаковую яркость по всем направлениям и излучает свет, интенсивность которого изменяется по закону косинуса $I=I_{0} \cos \theta$, где $I_{0}-$ интенсивность излучения в направлении нормали к поверхности, $\theta-$ угол между направлением наблюдателя и нормалью к поверхности [7]. Примером может служить белая бумага или молочное стекло. Показателем эффективности рассеяния поверхностью отраженного света с длиной волны $\lambda$ служит коэффициент диффузного отражения света (в англоязычной литературе - „Haze-factor“, $H(\lambda))$, который является отношением потока диффузно отраженного света $R_{\text {diff }}(\lambda)$ к полному $R_{\text {full }}(\lambda)$ потоку отраженного света: $H(\lambda)=R_{\text {diff }} / R_{\text {full. }}$ Элементами текстур могут быть выпуклые и вогнутые конусы, пирамиды, фасетки, столбики. Наиболее распространенными способами текстурирования поверхности кремния являются анизотропное жидкостное, плазменное травление и фотолитография [8,9]. В настоящее время в промышленных кремниевых НIT фотопреобразователях наибольшее применение получили пирамидальные текстуры, получаемые методом щелочного анизотропного травления. Однако при механических нагрузках пирамидальная геометрия текстуры приводит к концентрации напряжений вблизи оснований и вершин пирамид и при изгибающих напряжениях трещины легко развиваются по направлению (111) [10,11]. Эта особенность пирамидальной текстуры приводит к резкому увеличению вероятности растрескивания кремниевых пластин при изготовлении, транспортировке и эксплуатации ФЭП.

Еще одним источником механических напряжений приводящих к быстрому разрушению ФЭП и отслаиванию электродов, являются места пайки соединений токоведущих элементов ФЭП. Пайка токоведущих соединений является одной из наиболее сложных частей технологии изготовления ФЭП. В местах пайки соединяются несколько разнородных материалов, обладающих совершенно разными коэффициентами теплового расширения, что приводит к возникновению значительных механических напряжений при пайке и термическом циклировании в процессе эксплуатации. Кроме того, эти материалы обладают различными электрохимическими свойствами, что приводит к возникновению гальванических пар. Эти факторы ведут к отслаиванию, разрывам электродов и коррозии элементов ФЭП [12,13]. Еще одним фактором, приводящим к быстрому разрушению ФЭП, являются блуждающие токи, возникающие вследствие большой разности потенциалов между модулями ФЭП и его несущей конструкцией (potential induced degradation - PID). Это явление приводит к переносу ионов щелочных металлов, коррозии и возникновению коротких замыканий в $p-n$-переходах. К факторам, снижающим эффективность ФЭП, но не приводящим к его быстрому разрушению (группа 2), относится деградация, индуцированная светом (light induced degradation LID). К этой группе относятся потери, связанные с внутренним сопротивлением кремниевой пластины, омическим сопротивлением электродной системы и рекомбинацией носителей внутри ФЭП [14]. В дальнейшем мы будем касаться только технологии получения и свойств текстур на поверхности кремния и способов согласования КТР элементов конструкции солнечных фотопреобразователей.

\section{3. Особенности текстурирования поверхности монокристаллического кремния методом щелочного анизотропного травления}

В настоящее время в промышленных HIT фотопреобразователях наибольшее применение получили пирамидальные текстуры, получаемые методом щелочного анизотропного травления [15]. Эта технология позволяет создавать неупорядоченные пирамидальные текстуры с размерами от 0.5 до 4 мк на больших поверхностях кремния $(156 \times 156$ мм). Для получения достаточно однородной поверхностной структуры необходима предварительная обработка кремниевой пластины (удаление нарушенного слоя). В качестве текстурирующего реагента чаще всего используются водные растворы КОН. Взаимодействие кремния и текстурирующего раствора гидроксида калия описывается химической реакцией с образованием силиката калия и водорода:

$$
\mathrm{Si}+2 \mathrm{KOH}+\mathrm{H}_{2} \mathrm{O}=\mathrm{K}_{2} \mathrm{SiO}_{3}+2 \mathrm{H}_{2} \uparrow .
$$

В процессе анизотропного жидкофазного химического травления на поверхности кремния образуются пирамиды, грани которых оказываются кристаллографическими плоскостями. Формирование такого микрорельефа объясняется сильной зависимостью скорости травления кристалла от ориентации кристаллографических плоскостей. Самая низкая скорость травления наблюдается на плоскости (111), так как плотность упаковки атомов здесь выше всего. В результате наиболее эффективно пирамиды формируются на монокристаллических подложках кремния с ориентацией (100), которые и используются при производстве ФЭП полупроводников. Для получения ровной огранки пирамид в раствор добавляются поверхностно активные вещества, обычно изопропиловый спирт. Далее, с поверхности текстурированных пластин удаляется тонкий слой образовавшегося оксида кремния, осаждаются пассивирующие слои и слои аморфного кремния. На полученную структуру осаждается слой ППО, выполняющий также функцию антиотражающего покрытия. Изображение скола такой структуры, полученное с помощью сканирующего электронного микроскопа JSM 7001F (Jeol, Япония), показано на рис. 1. Несмотря на доступность и технологическое изящество, анизотропное щелочное текстурирование имеет и недостатки. Прежде всего идеальное 


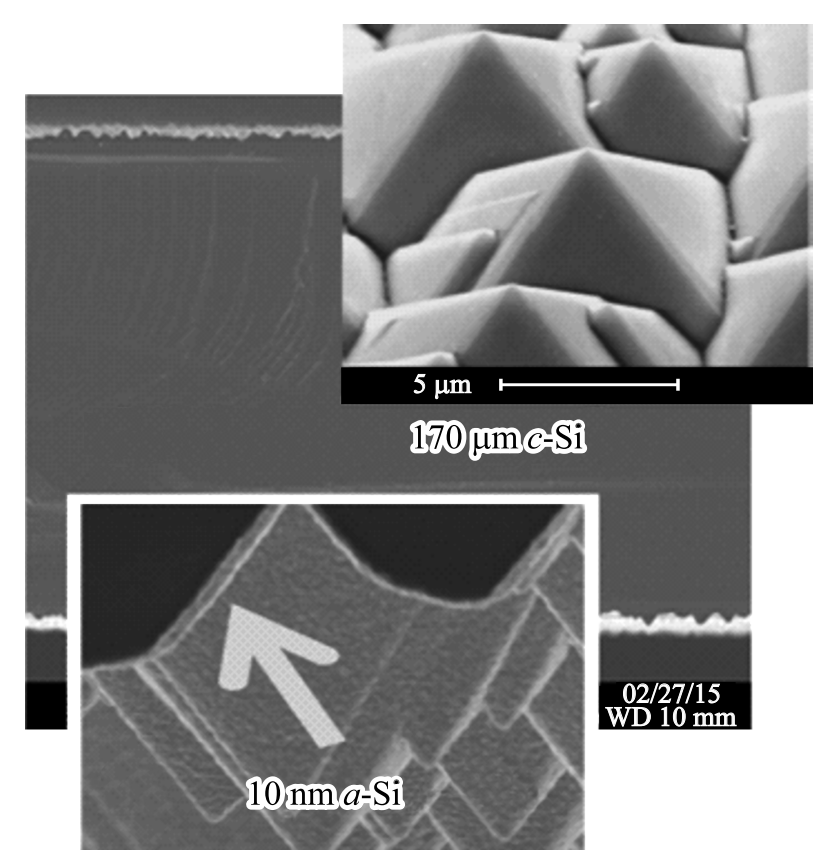

Рис. 1. Микроизображение скола кремниевой НІТ структуры. Светлые области - слои аморфного кремния и прозрачного проводящего оксида.

диффузное рассеяние с трудом достигается даже на одной длине волны и не реализуемо в пирамидальных структурах, не говоря о широком диапазоне длин волн [7]. В работе [16] исследовано отражение видимого света в зависимости от усредненного размера пирамид в текстурах и экспериментально показано, что заметное уменьшение отражения начинается с размера пирамид $\sim 0.2$ мкм. Изменение размера пирамид от 1 до 10 мкм не приводит к существенному снижению отражения света. Кроме концентрации механических напряжений вблизи оснований и вершин пирамид и хрупкости в направлении (111), эта технология имеет особенности, связанные с процессом текстурирования. Реакция (1) сопровождается выделением пузырьков водорода на поверхности кремния, что приводит к различию в скоростях реакции (1) на различных участках кремния и образованию ступенек и кратеров, которые являются центрами рекомбинации электронов и дырок [17]. В работе [18] обнаружена более чем 10-кратная зависимость интенсивности электролюминесценции при увеличении кпд гетеропереходных ФЭП на основе монокристаллического кремния от 18 до 20.5\%. Причинами эффекта является резкое изменение концентрации центров рекомбинации на поверхности пластин монокристаллического кремния в процессе их пирамидального текстурирования, а также увеличение последовательного сопротивления. Реакция (1) протекает при температуре $70-80^{\circ} \mathrm{C}$, когда, кроме выделения водорода, происходит интенсивный гидролиз $\mathrm{K}_{2} \mathrm{SiO}_{3}$ с образованием геля оксида кремния. При больших концентрациях силиката калия пленка образующегося $\mathrm{SiO}_{2}$ затрудняет транспорт реагентов к поверхности кремния, что приводит к значительному разбросу скоростей травления на различных участках поверхности кремния. Поэтому на гранях формирующихся пирамид возрастает вероятность возникновения многочисленных дефектов и ступенек, которые играют роль рекомбинационных центров и негативно сказываются на итоговой эффективности ФЭП. Из сказанного следует, что необходим поиск новых способов текстурирования и согласования КТР материалов конструкции ФЭП, что должно привести к улучшению прочностных и эксплуатационных характеристик кремниевых ФЭП.

\section{4. Текстурирование поверхности монокристаллического кремния с помощью окисления под тонким слоем $\mathrm{V}_{2} \mathrm{O}_{5}$}

Создание текстуры на поверхности кремния возможно с помощью его неоднородного окисления, когда в качестве инициирующих центров окисления используются дефекты кремния с последующим растворением областей оксида в плавиковой кислоте. Функцию инициирующих центров могут выполнять места выхода дислокаций, или преципитаты $\mathrm{SiO}_{x}(x \leq 2)$. В современных $\mathrm{Cz}-\mathrm{Si}$ монокристаллах концентрация дислокаций на поверхности не превышает $10^{2} \mathrm{~cm}^{-2}$, что недостаточно для создания сплошных текстур с размерами 400-800 нм. В то же время концентрация преципитатов кислорода, возникающих при росте монокристаллов $\mathrm{Cz}$-кремния, находится в диапазоне $10^{11}-10^{13} \mathrm{~cm}^{-3}[19,20]$, что достаточно для создания текстур субмикронных размеров. В наших работах [21,22] исследован процесс текстурирования поверхности монокристаллического кремния, окисленного под слоем $\mathrm{V}_{2} \mathrm{O}_{5}$, основанный на возникновении преципитатов $\mathrm{SiO}_{x}$ в кремнии, диффузии атомарного кислорода из $\mathrm{V}_{2} \mathrm{O}_{5}$ через слой $\mathrm{SiO}_{2}$ к кремнию и последующего растворения оксида кремния и $\mathrm{V}_{2} \mathrm{O}_{5}$ в плавиковой кислоте. В этих экспериментах использовались полированные пластины монокристаллического кремния, как $n$-, так и $p$-типа с концентрацией кислорода $\sim 10^{18} \mathrm{~cm}^{-3}$. На поверхность кремния осаждался слой металлического ванадия толщиной 70-80 нм, который окислялся до предельного оксида ванадия $\left(\mathrm{V}_{2} \mathrm{O}_{5}\right)$ при температуре $723 \mathrm{~K}$. Далее производился отжиг полученной структуры при температуре $903 \mathrm{~K}$ в кислороде или на воздухе. При этой температуре начинается взаимодействие $\mathrm{V}_{2} \mathrm{O}_{5}$ и кремния, приводящее к окислению кремния и восстановлению металла в $\mathrm{V}_{2} \mathrm{O}_{5}$. Восстановление оксида до металла необязательно, достаточно того, чтобы металл изменил свое валентное состояние от $\mathrm{Me}^{+n}$ до $\mathrm{Me}^{+(n-1)}$. В частности, реакция восстановления $\mathrm{V}^{+5}$ до $\mathrm{V}^{+4}$ выглядит следующим образом:

$$
\mathrm{Si}+2 \mathrm{~V}_{2} \mathrm{O}_{5}=\mathrm{SiO}_{2}+4 \mathrm{VO}_{2} .
$$

Энергия Гиббса $(\Delta G)$ этой реакции при 903-923 К отрицательна $(\Delta G \sim-680$ кДж/моль), следовательно, эта 

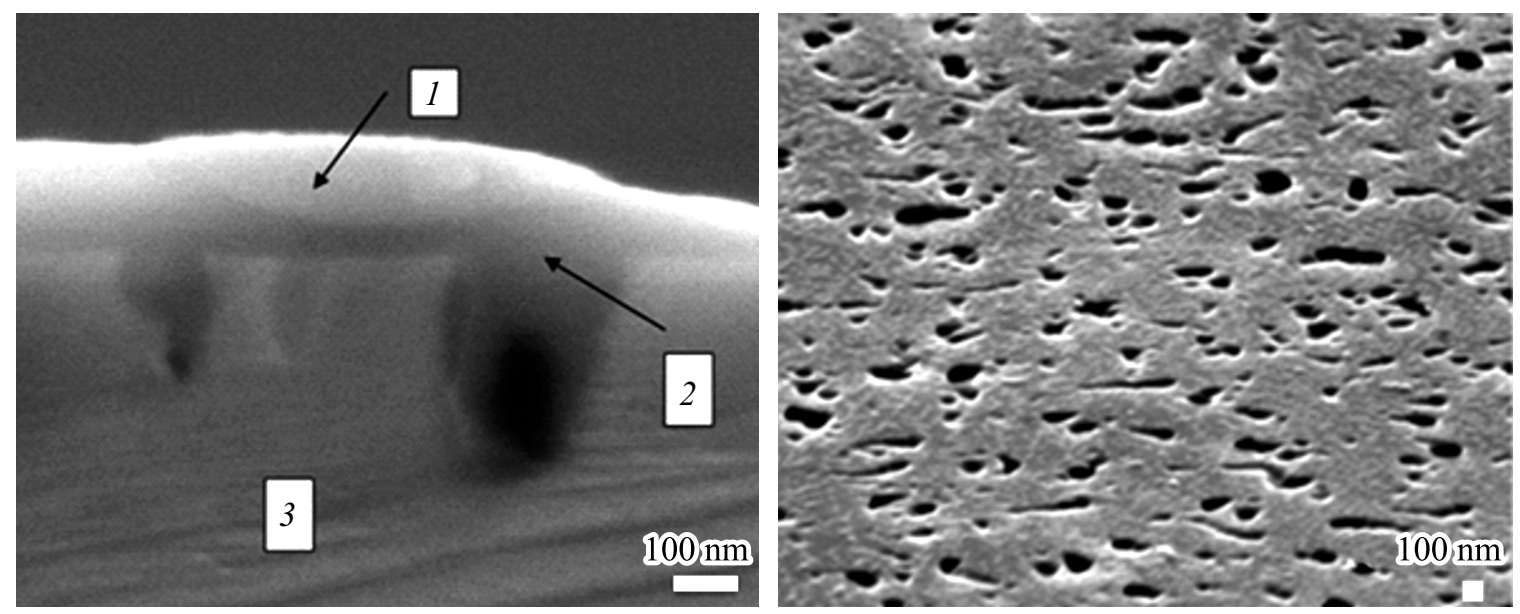

Рис. 2. СЭМ-изображения скола структуры $\mathrm{Si}-\mathrm{SiO}_{2}-\mathrm{V}_{2} \mathrm{O}_{5}$ после отжига при $903 \mathrm{~K}$ (слева) и поверхности кремния после удаления слоев $\mathrm{SiO}_{2}$ и $\mathrm{V}_{2} \mathrm{O}_{5}$ в плавиковой кислоте (справа). 1 - поверхностный слой $\mathrm{V}_{2} \mathrm{O}_{5}, 2-$ слои $\mathrm{SiO}_{2}, 3-$ кремниевая подложка.

реакция осуществима. Электронно-микроскопическое исследование (СЭМ JSM 7001F) сколов структуры, полученной при $903 \mathrm{~K}$, показало, что на этой стадии отжига происходит интенсивное взаимодействие на границе $\mathrm{V}_{2} \mathrm{O}_{5}$ и кремния (рис. 2, слева). Электронномикроскопическое исследование показывает также, что слой оксида кремния, образовавшийся при $903 \mathrm{~K}$ имеет существенный разброс по толщине, находящийся в пределах от 30 до 400 нм. Можно выделить плоские участки этого слоя толщиной 30-50нм, между которыми находятся глубокие включения (до $400 \mathrm{Hм}$ ). Увеличение времени отжига более 1 ч при $903 \mathrm{~K}$ не приводит к увеличению толщины образующегося слоя диоксида кремния. Таким образом, при отжиге интенсивное окисление кремния на границе $\mathrm{Si}-\mathrm{V}_{2} \mathrm{O}_{5}$ начинается при температуре $903 \mathrm{~K}$, что существенно ниже, чем при обычном термическом окислении в кислородсодержащей атмосфере. Толщина плоских областей оксида кремния $30-50$ нм, что в 5-6 раз больше, чем толщина $\mathrm{SiO}_{2}$, образующегося при термическом окислении кремния в кислороде при аналогичных температурно-временны́х режимах. Неоднородность окисления кремния можно связать с существованием преципитатов $\mathrm{SiO}_{x}$. Известно, что ниже $573 \mathrm{~K}$ кислород находится в кремнии в виде пересыщенного раствора. Термические обработки выше $703 \mathrm{~K}$ приводят к распаду пересыщенного раствора и появлению в объеме кремния микроскопических преципитатов аморфного субоксида кремния $\alpha-\mathrm{SiO}_{x}[19,20]$. Для подтверждения образования преципитатов $\mathrm{SiO}_{x}$ в объеме кремния в процессе использованных термических обработок были измерены ИК-спектры исходных пластин кремния и пластин кремния после отжига в температурных режимах, идентичных использованным для приготовления текстурированных образцов. Двухступенчатый отжиг пластин кремния и 723 K (1 ч) +903 K (1 ч) осуществлялся в атмосфере чистого азота. Спектры снимались с помощью фурье-спектрометра FTIR Shimadzu8400 s в диапазоне $400-4000 \mathrm{~cm}^{-1}$ (рис. 3). Для исходных пластин кремния характерно наличие сильной полосы поглощения с максимумом в области $1107 \mathrm{~cm}^{-1}$, связанной с асимметричными валентными колебаниями связей $\mathrm{Si}-\mathrm{O}-\mathrm{Si}$ (мода растяжения). Концентрация кислорода в исходных образцах $\sim 1.2 \cdot 10^{18} \mathrm{~cm}^{-3}$. После двухступенчатого отжига в атмосфере высокочистого азота полоса поглощения уширяется, максимум ее немного смещается. Спектр пропускания отожженного образца относительно исходного имеет четкий максимум $1067 \mathrm{~cm}^{-1}$, что подтверждает появление в кремниевых пластинах после отжига в инертной атмосфере аморфного субоксида кремния $\mathrm{SiO}_{x}(x \leq 2)$. Образование преципитатов $\mathrm{SiO}_{x}$ в кремнии происходит одновременно с твердофазной реакцией $\mathrm{V}_{2} \mathrm{O}_{5}$ и кремния. Из-за разности параметров решеток, коэффициентов термического расширения

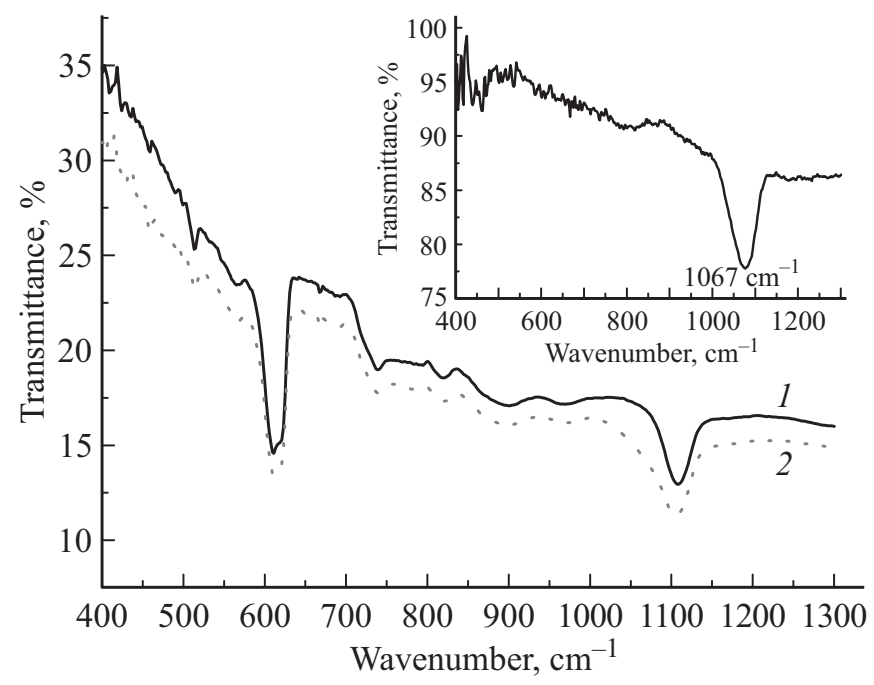

Pис. 3. Спектры пропускания исходной пластины кремния до (1) и после (2) двухступенчатого отжига при $723 \mathrm{~K}$, 1 ч $+903 \mathrm{~K}, 1$ ч. На вставке - спектр пропускания отожженного образца относительно исходного. 
кремния и преципитатов $\mathrm{SiO}_{x}$ в образцах возникают деформации. В результате в кремнии вблизи границы $\mathrm{Si}-\mathrm{V}_{2} \mathrm{O}_{5}$ образуются микроучастки с высокой концентрацией дефектов, где коэффициент диффузии кислорода и скорость реакции (2) существенно больше, чем на остальной поверхности кремния. Эти области являются инициирующими центрами, ускоряющими окисление кремния. В результате на границе $\mathrm{Si}-\mathrm{V}_{2} \mathrm{O}_{5}$ образуется неоднородный по толщине слой $\mathrm{SiO}_{2}$ с включениями оксида кремния в кремний глубиной до 400 нм. Полученные результаты позволяют также сделать выводы о механизме ускоренного окисления кремния под слоем $\mathrm{V}_{2} \mathrm{O}_{5}$. Обычно поверхность кремния перед окислением уже покрыта тонким слоем оксида, и по мере его роста все более существенную роль начинает играть скорость переноса кислорода к границе $\mathrm{SiO}_{2}-\mathrm{Si}$. На начальной стадии окисления зависимость толщины пленки от времени определяется диффузией кислорода к границе $\mathrm{SiO}_{2}-\mathrm{Si}$ и выражается параболической зависимостью от времени. В дальнейшем зависимость толщины оксида от времени становится логарифмической и рост пленки прекращается. Поэтому основной вклад в зависимость толщины пленки $\mathrm{SiO}_{2}$ от времени вносит параболический участок. $\mathrm{B}$ простейшем случае одномерной диффузии кислорода толщина слоя $\mathrm{SiO}_{2}-h$ выражается формулой

$$
h=\sqrt{2 D t},
$$

где $D-$ коэффициент диффузии, $t-$ время.

Подставив в (3) измеренные толщины слоя оксида кремния, образовавшегося за 1 ч на различных участках поверхности кремния при температуре $903 \mathrm{~K}$, можно оценить значения коэффициента диффузии кислорода на этих участках. Для плоских участков $(h \sim 40$ нм $)$ $D_{1} \approx 2 \cdot 10^{-15} \mathrm{~cm}^{2} \cdot \mathrm{c}^{-1}$. Для участков поверхности кремния с глубокими включениями диоксида кремния $(h \sim 400$ нм) вычисленный коэффициент диффузии кислорода намного больше $D_{2} \approx 2 \cdot 10^{-13} \mathrm{~cm}^{2} \cdot \mathrm{c}^{-1}$. Сравним эти результаты с параметрами термического окисления кремния в сухом кислороде при тех же температуpax. Толщина слоя оксида кремния $h$ образующегося при $973 \mathrm{~K}$ в атмосфере сухого кислорода за 1 ч, $\leq 10$ нм и оценочное значение коэффициента диффузии кислорода $D_{\text {dry }} \approx 1 \cdot 10^{-17} \mathrm{~cm}^{2} \cdot \mathrm{c}^{-1}[23]$.

Большое различие в коэффициентах диффузии кислорода указывает на существенную разницу в механизме транспорта кислорода через слой $\mathrm{SiO}_{2}$ при окислении кремния в среде кислорода и при окислении кремния под слоем $\mathrm{V}_{2} \mathrm{O}_{5}$. В ряде работ $[24,25]$ исследован процесс ускоренного окисления кремния при температурах 723-973 К в смесях кислород-озон, где присутствует атомарный кислород, возникающий вследствие разложения молекул озона. В этих работах показано, что при температуре $873 \mathrm{~K}$ в течение 20 мин толщина слоя оксида достигает 7-8 нм. Увеличение скорости окисления кремния в среде $\mathrm{O}_{2} / \mathrm{O}_{3}$ связывается с присутствием атомарного кислорода. Из-за малого радиуса атома кислорода его коэффициент диффузии через слой $\mathrm{SiO}_{2}$ существенно больше, чем у молекулярного кислорода, что и объясняет увеличение скорости окисления. Увеличение скорости твердофазного окисления кремния под слоем $\mathrm{V}_{2} \mathrm{O}_{5}$ можно объяснить влиянием двух факторов. Естественно предположить, что окисление кремния происходит путем перемещения атомов кислорода от $\mathrm{V}_{2} \mathrm{O}_{5}$ к кремнию, что приводит к увеличению коэффициента диффузии кислорода через слой растущего оксида кремния. Вторым фактором, влияющим на скорость окисления, является разница химических потенциалов кислорода $\Delta \mu$ на внешней поверхности диоксида кремния и в слое на границе $\mathrm{SiO}_{2}-\mathrm{Si}$. В соответствии с законом Фика поток диффундирующих частиц $J$ пропорционален градиенту химического потенциала: $J=D_{d h}^{d \mu}$, где $h-$ толщина оксида кремния, $D-$ коэффициент диффузии. Основной вклад в градиент химического потенциала вносит разность концентраций кислорода на поверхности растущего оксида и в слое вблизи границы $\mathrm{SiO}_{2}-\mathrm{Si}$. В случае окисления из газовой среды концентрация кислорода вблизи внешней поверхности $\mathrm{SiO}_{2}$ равна $\sim 3 \cdot 10^{19} \mathrm{~cm}^{-3}$, в то время как при твердофазном окислении концентрация атомов кислорода, находящегося на поверхности кремния, соответствует концентрации кислорода в $\mathrm{V}_{2} \mathrm{O}_{5}$ и равна $\sim 5 \cdot 10^{22} \mathrm{~cm}^{-3}$. Сравнение концентраций показывает, что при твердофазном окислении диффузия кислорода происходит в существенно большем градиенте химического потенциала, что является дополнительным фактором, увеличивающим скорость окисления кремния. Для непрерывного протекания реакции (2) необходимо поддерживать состав пленки $\mathrm{V}_{2} \mathrm{O}_{5}$ постоянным. В работе [26] исследован процесс окисления ванадия в атмосфере кислорода при температуре $873 \mathrm{~K}$ и показано, что при этой температуре величина коэффициента диффузии кислорода в $\mathrm{V}_{2} \mathrm{O}_{5}$ равна $\sim 3 \cdot 10^{-11} \mathrm{~cm}^{2} \cdot \mathrm{c}^{-1}$, что на несколько порядков больше, чем коэффициент диффузии кислорода через пленку оксида кремния. Поэтому расход кислорода из пленки $\mathrm{V}_{2} \mathrm{O}_{5}$ на окисление кремния восполняется за счет поступления кислорода из газовой фазы. Поскольку $\mathrm{V}_{2} \mathrm{O}_{5}$ участвует в реакции (2), но не расходуется, можно сделать вывод, что пленка $\mathrm{V}_{2} \mathrm{O}_{5}$ является хемостимулятором окисления кремния и выполняет функцию донора атомарного кислорода. Из-за низких значений коэффициента диффузии кислорода в оксиде кремния при достижении критической толщины слоя $\mathrm{SiO}_{2}$ скорость окисления кремния становится пренебрежимо малой и рост слоя оксида прекращается. После растворения $\mathrm{SiO}_{2}$ и $\mathrm{V}_{2} \mathrm{O}_{5}$ в плавиковой кислоте на поверхности пластины кремния образуется текстурированный слой с очень своеобразной геометрией (рис. 2, справа). Как видно из микроизображений, поверхность кремния состоит из многочисленных вогнутых сфероидов с размерами от 100 до 500 нм и глубиной до 400 нм, которые разделены между собой относительно гладкими областями размерами 300-1000 нм. Текстурированная поверхность кремния обладает ярко выраженными поглощающими и рассеивающими свойствами в области длин волн видимого света. Измерение спектров отражения проводилось 


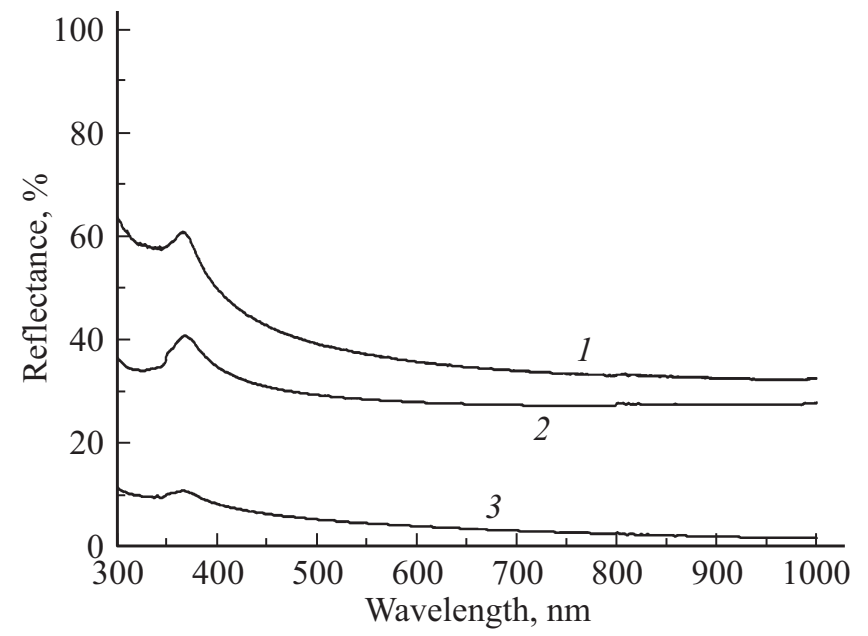

Pис. 4. Спектры отражения поверхности кремния: $1-$ полное отражение от полированной поверхности кремния, 2 - полное отражение от текстурированной поверхности кремния, 3 - диффузное отражение от текстурированной поверхности кремния.

на спектрофотометре Cary 5000 UV-Vis-NIR (рис. 4). Исходная (полированная) поверхность кремния имела пренебрежимо малое диффузное рассеяние $(H(\lambda) \leq 1 \%)$ в области длин волн 300-1000 нм. После текстурирования кремния наибольшие изменения в отражении наблюдались в области длин волн $330-550$ нм, где полное отражение $\left(R_{\text {full }}(\lambda)\right)$ уменьшалось в $1.7-1.33$ раза. Диффузное отражение $R_{\text {diff }}(\lambda)$ увеличилось до $\sim 9 \%$ при 380 нм и до $\sim 6 \%$ на длине волны 500 нм. Следовательно, $H(380$ нм $) \sim 24 \%, H(500$ нм $) \sim 17 \%$. Полученная текстура на поверхности кремния интенсивно рассеивает отраженный свет в области длин волн $300-550$ нм, что может быть использовано при создании эффективных солнечных фотопреобразователей.

\section{5. Согласование теплового расширения токоведущих элементов конструкции фотопреобразователя с использованием слоев железоникелевых сплавов}

Система электродов на фронтальной поверхности НIT фотопреобразователей состоит из втягивающих и коллекторных электродов. Для создания системы токосъемных электродов в НIT фотопреобразователях используются проводящие пасты на основе серебра $[12,13]$. Паста наносится через трафарет на текстурированную фронтальную поверхность фотопреобразователя, полученная структура подвергается отжигу при $\sim 200^{\circ} \mathrm{C}$, после чего производится пайка медных коллекторных шин. Поэтому одним из частых дефектов, возникающих при изготовлении НIT солнечных фотопреобразователей, является растрескивание серебряных электродов и их отслаивание от слоя ППО, связанное с большой разницей КТР серебра, меди, кремния и ППО. Это явление проявляется также при суточном термоциклировании в процессе эксплуатации ФЭП. Одной из причин отслоения электродов в процессе эксплуатации ФЭП является возникновение крупных серебряных кристаллитов, связанное с циклическим нагревом и охлаждением [13]. В этом случае крупные серебряные кристаллиты непосредственно контактируют со слоем ППО и даже кремнием и разница КТР серебра $\left(\alpha \sim 19.5 \cdot 10^{-6} \mathrm{~K}^{-1}\right)$ и $\mathrm{Si}\left(\alpha \sim 2.6 \cdot 10^{-6} \mathrm{~K}^{-1}\right)$, ППО $\left(\alpha \sim 6 \cdot 10^{-6} \mathrm{~K}^{-1}\right)$ становится очень заметной, что приводит к отслоению электродов [16]. В патенте [27] нами предложен способ согласования коэффициентов теплового расширения коллекторных электродов и фронтального слоя прозрачного проводящего оксида, основанный на применении в конструкции ФЭП дополнительных субслоев железоникелевых сплавов. Особенность железоникелевых сплавов состоит в том, что в зависимости от соотношения в них железа и никеля коэффициент термического расширения КТР этих сплавов изменяется в пределах $(2-20) \cdot 10^{-6} \mathrm{~K}^{-1}$ [28]. Зависимость КТР железоникелевых сплавов от их состава имеет сложный характер и показана на рис. 5. Так как парциальные давления паров железа и никеля при температурах их испарения очень близки, легко получать стехиометрические слои этих сплавов различными способами термического вакуумного испарения. Возможно также осаждение слоев железоникелевых сплавов лазерной абляцией. Кроме того, эти сплавы хорошо паяются легкоплавкими припоями. Наибольшие токи протекают через коллекторные электроды, следовательно, здесь и происходит наибольший нагрев. Поэтому целесообразно наносить слои железоникелевого сплава под коллекторными шинами, причем токособирающие электроды из серебряной пасты частично перекрывают слои железоникелевого сплава. Значение КТР железоникелевого сплава

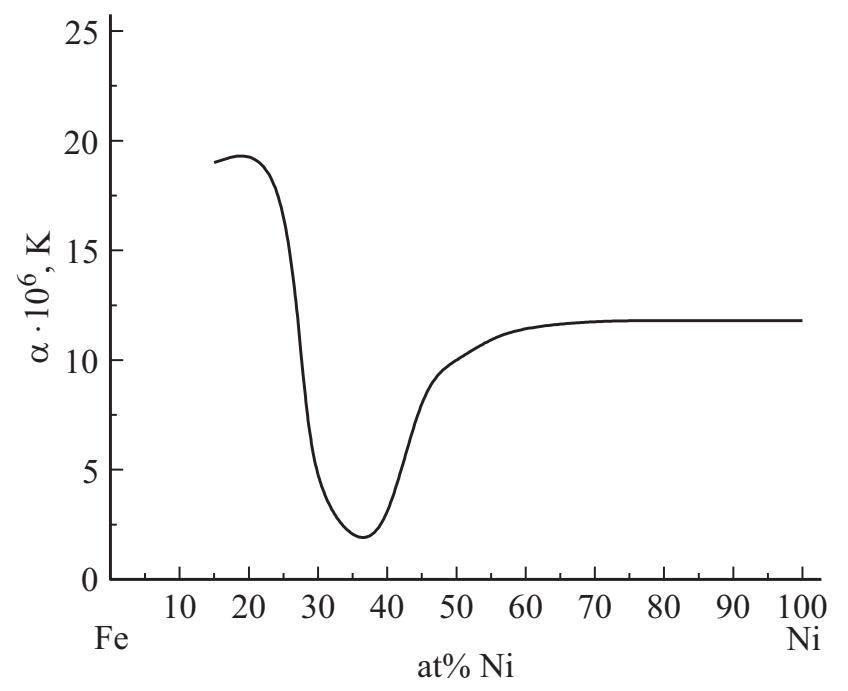

Рис. 5. Зависимость КТР сплавов железо-никель от состава [28]. 

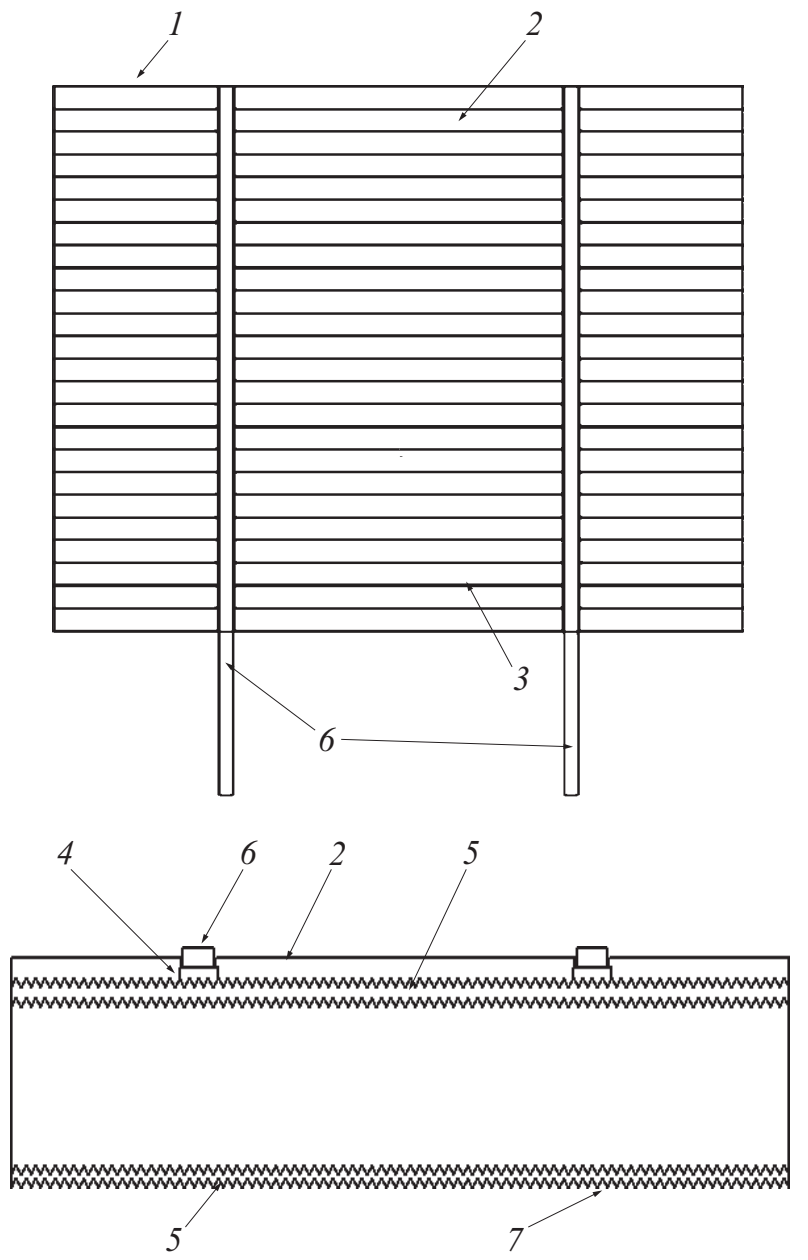

Рис. 6. Конструкция кремниевого НІТ фотоэлемента с согласующими железоникелевыми слоями. 1 - НІТ кремниевый солнечный элемент, 2 - прозрачный проводящий оксид, 3 - токосборные контакты из серебросодержащей пасты, 4 - согласующие токосъемные слои из сплава железа-никеля, 5 - слои аморфного кремния; 6 - коллекторная металлическая шина, спаянная с токосъемным железоникелевым слоем, 7 - тыльный металлический электрод.

выбирается промежуточным между КТР прозрачного проводящего оксида и материалом коллекторной шины. Толщина субслоев составляет $\sim 1$ мк, ширина $\sim 1.5$ мм. Далее к железоникелевым слоям легкоплавким припоем на основе олова в местах контактов с токособирающими электродами паяются луженые медные коллекторные шины. Железоникелевые субслои и низкоомная шина коллекторного электрода оказываются включенными параллельно, и, так как сопротивление медной шины много меньше, чем сопротивление субслоя, практически весь ток течет по медной шине. Модули сдвига меди и ППО находятся в интервале 30-47 ГПа, а модули сдвига оловянных припоев в 3-5 раз меньше (5-10 ГПа) [29]. Поэтому возникающие напряжения при пайке и суточном термоциклировании ФЭП релаксируют в материале припоя. Схематически конструкция кремниевого НIT фотоэлемента с согласующими железоникелевыми слоями показана на рис. 6. В условиях эксплуатации солнечных фотопреобразователей суточные колебания температур (с учетом собственного нагрева фотопреобразователя) достигают 50 и более градусов. С учетом КТР это приводит к периодическому расхождению геометрических размеров прозрачного проводящего покрытия и металлических коллекторных электродов. Согласование КТР прозрачного проводящего покрытия и медных шин с помощью железоникелевого субслоя приводит к плавному распределению механических напряжений вблизи контакта ППО-коллекторный электрод. Согласно техническим требованиям на надежность электродов в течение 30 лет, это дает резкое уменьшение вероятности деградации (отказов) по механизму отслаивания и возникновению трещин в конструкции кремниевых ФЭП.

\section{6. Заключение}

Анализ литературных данных показывает, что около 30\% отказов высокоэффективных кремниевых солнечных ФЭП происходит из-за образования трещин в кремниевых пластинах и электродах. Механические напряжения, приводящие к растрескиванию, возникают при пайке электродов, и в результате суточного термоциклирования при эксплуатации ФЭП, что связано с разностью КТР элементов конструкции. Пирамидальная геометрия текстуры дополнительно приводит к концентрации напряжений вблизи оснований и вершин пирамид и трещины легко развиваются по направлению (111). Для улучшения прочностных и эксплуатационных характеристик кремниевых ФЭП необходим поиск новых методов создания текстур и согласования КТР материалов конструкции ФЭП.

В данной работе предложен способ текстурирования поверхности кремния с помощью его неоднородного окисления под тонким слоем $\mathrm{V}_{2} \mathrm{O}_{5}$, с последующим растворением областей оксида. В качестве инициирующих центров окисления используются дефекты кремния. Функцию инициирующих центров окисления могут выполнять преципитаты $\mathrm{SiO}_{x}$ и места выхода дислокаций. Полученная текстура состоит из вогнутых сфероидов

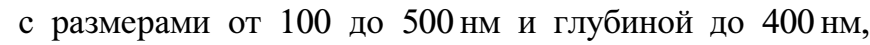
разделенных между собой гладкими областями размерами 300-1000 нм. Такая поверхность кремния обладает ярко выраженными поглощающими и рассеивающими свойствами в области длин волн видимого света. Для согласования КТР коллекторных электродов и фронтальных слоев прозрачного проводящего оксида авторами предложена методика, основанная на применении в конструкции ФЭП дополнительных субслоев железоникелевых сплавов. Особенность железоникелевых сплавов состоит в том, что в зависимости от соотношения в них железа и никеля КТР этих сплавов изменяется в очень широких пределах $(2-20) \cdot 10^{-6} \mathrm{~K}^{-1}$. Значение КТР железоникелевого сплава выбирается промежуточным между КТР прозрачного проводящего оксида и материалом коллекторной шины. Согласование КТР 
прозрачного проводящего покрытия и медных шин с помощью железоникелевого слоя приводит к плавному распределению механических напряжений вблизи контакта ППО-коллекторный электрод, что резко уменьшает вероятность отслаивания электродов и возникновения трещин в конструкции кремниевых ФЭП.

Работа выполнена при поддержке РФФИ гранта 18-58-41005. Электронно-микроскопические изображения были частично выполнены на оборудовании ЦКП „Материаловедение и диагностика в передовых технологиях“.

\section{Список литературы}

[1] M. Taguchi, A. Yano, S. Tohoda, K. Matsuyama, Y. Nakamura, T. Nishiwaki, K. Fujita, E. Maruyama. IEEE J. Photovolt., 4, 96 (2014).

[2] J. Kegel, H. Angermann, U. Stürzebecher, E. Conrad, M. Mews, L. Korte, B. Stegemann. Appl. Surf. Sci., 301, 56 (2014).

[3] S. Kasap, P. Capper (eds). Springer Handbook of Electronic and Photonic Materials, Springer International Publishing AG 2017.

[4] A. Green, Y. Hishikawa, W. Warta, E.D. Dunlop, D.H. Levi, J. Hohl-Ebinger, A.W.Y. Ho-Baillie. Prog. Photovolt. Res. Appl., 25, 668 (2017).

[5] ITRPV, 8th edn (September, 2017). http://www.semi.org/sites/ semi.org/files/docs/ITRPV_2014_Roadmap_Revision1_ 140324.pdf

[6] M. Köntges, S. Kurtz, U. Jahn, K.A. Berger, K. Kato, H. Liu, T. Friesen, M. Van Iseghem. Review of Failures of Photovoltaic Modules. Report IEA-PVPS T13-01:2014.

[7] L. Forbes. Solar Energy, 86, 319 (2012).

[8] M. Edwards, S. Bowden, U. Das, M. Burrows. Solar Energy Mater. \& Solar Cells, 92, 1373 (2008).

[9] [M. Moreno, D. Murias, J. Martínez, C. Reyes-Betanzo, A. Torres, R. Ambrosio, P. Rosales, P. Roca i Cabarrocas, M. Escobar. Solar Energy, 101, 182 (2014).

[10] A. Buchler, A. Beinert, S. Kluska, V. Haueisen, P. Romer, F.D. Heinz, M. Glatthaar, M. Schubert. Energy Procedia, 124, 18 (2017).

[11] J. Rion, Y. Leterrier, J.-A.E. Menson. J.-M. Blairon. Composites: Pt A, 40, 1167 (2009).

[12] M.T. Zarmai, N.N. Ekere, C.F. Oduoza, E.H. Amalu. Appl. Energy, 154, 173 (2015).

[13] T. Aoyama, M. Aoki, I. Sumita, Y. Yoshino1, Y. Ohshita, A. Ogura. Jpn. J. Appl. Phys., 56, 102302 (2017).

[14] arXiv:1801.04245v1 [physics.app-ph] 12 Jan 2018 site:export.arxiv.org

[15] H. Angermann, A. Laades, U. Stürzebecher, E. Conrad, C. Klimm, T.F. Schulze, K. Jacob, A. Lawerenz, L. Korte. Sol. St. Phenomena, 187, 349 (2012).

[16] Y. Han, X. Yu, D. Wang, D. Yang. J. Nanomaterials, 716012 , 5 (2013).

[17] [A.K. Chu, J.S. Wang, Z.Y. Tsai, C.K. Lee. Sol. Energy Mater. \& Solar Cells, 93, 1276 (2009).

[18] В.Н. Вербицкий, И.Е. Панайотти, С.Е. Никитин, А.В. Бобыль, Г.Г. Шелопин, Д.А. Андроников, А.С. Абрамов, А.В. Саченко, Е.И. Теруков. Письма ЖТФ, 43 (17), 3 (2017).
[19] A. Borghesi, B. Pivac, A. Sassella, A. Stella. J. Appl. Phys., 77, 4169 (1995).

[20] J.D. Murphy, R.E. McGuire, K. Bothe, V.V. Voronkov, R.J. Falster. Solar Energy Mater. \& Solar Cells, 120, 402 (2014).

[21] С.Е. Никитин, Е.Е. Терукова, А.В Нащекин, А.В Бобыль. Патент РФ № 2600076.

[22] С.Е. Никитин, Е.Е. Терукова, А.В. Нащекин, А.В. Бобыль, И.Н. Трапезникова, В.Н. Вербицкий. ФТП, 51 (1), 105 (2017).

[23] А.И. Курносов, В.В. Юдин. Технология производства полупроводниковых приборов и интегральных микросхем (М., Высш. шк., 1986) гл. 7, с. 118.

[24] A. Kazor, R. Gwilliam, Ian W. Boyd. Appl. Phys. Lett., 65, 412 (1994).

[25] Zh. Cui, J.M. Madsen, Ch.G. Takoudis. J. Appl. Phys., 87, $8181(2000)$

[26] J.R. Wilson, M.E. Levis. Nature, 206, 1350 (1965).

[27] С.Е. Никитин, А.В. Бобыль, Г.А. Иванов, Е.И. Теруков. Патент РФ № 172396.

[28] В.Б. Арзамасов, А.Н. Волчков и др. Материаловедение и технология конструкционных материалов (М., Издательский центр „Академия“, 2007).

[29] А. Парфенов. Технологии в электронной промышленноcmu, № 2 (2008) (http://tech-e.ru/2008_2_46.php).

Редактор А.Н. Смирнов

\section{New technological approaches to the creation of textures and matching of thermal expansion in the design of high-efficient silicon solar photovoltaic cells}

\author{
S.E. Nikitin ${ }^{1}$, A.V. Bobyl1,2, N.R. Avezova ${ }^{3}$, \\ E.I. Terukov ${ }^{1}$ \\ ${ }^{1}$ loffe Institute, \\ 194021 St. Petersburg, Russia \\ 2 St. Petersburg Electrotechnical University "LETI", \\ 197376 St. Petersburg, Russia \\ 3 Physicotechnical Institute NGO „Physics-sun“, \\ Uzbekistan Academy of Sciences, \\ 100084 Tashkent, Uzbekistan
}

\begin{abstract}
The causes of failures of high-efficient silicon solar photovoltaic cells are considered. About $30 \%$ of failures occur due to cracks in silicon wafers and electrodes. Mechanical stresses leading to cracks are associated with the pyramid geometry of the texture and the difference in thermal expansion of the materials of the structure. A new method of silicon texturing is described, where $\mathrm{SiO}_{x}$ precipitates perform the function of the texture nuclei, which allows to obtain a surface consisting of concave spheroids of submicron size, which sharply reduces the reflection in the wavelength range $330-550 \mathrm{~nm}$. The proposed method of matching thermal expansion of elements of the photovoltaic devices using matching layers of iron-nickel alloys, which gives a significant reduction of the failure probability for the mechanism of formation of cracks in silicon wafers and exfoliation of the electrodes.
\end{abstract}

